\author{
Anna Mazur \\ Wydział Filologiczny \\ Uniwersytet Mikołaja Kopernika w Toruniu \\ e-mail: mazurzanka@poczta.onet.pl
}

\title{
Modlitewna skarga „ani przeciw ludziom - ani przeciw Bogu”. Refleksja nad motywem łez w dwóch wierszach Juliusza Słowackiego
}

Interpretacja dwóch wierszy Słowackiego - I porzuciwszy drogé światowych omamień oraz Panie, o którym na niebiosach styszę... - jest podyktowana dążeniem do ukazania romantycznej uczuciowości czytanej przez pryzmat motywu łez w sytuacji przemiany wewnętrznej poety pod wpływem religijnych przeżyć. $W$ wybranych przeze mnie lirykach motyw pełni ważną rolę kompozycyjną i semantyczną, ponieważ kumuluje sensy zawarte w utworach. Jego duża frekwencja w tekstach nie tylko Słowackiego, ale także innych twórców romantycznych - Adama Mickiewicza, Zygmunta Krasińskiego, Cypriana Norwida skłania do zastanowienia się nad rolą motywu, który wiąże się między innymi z ekspresją różnorodnych uczuć podmiotu mówiącego. Sprawdzenia wymagają zatem takie hipotezy jak:

1) łza jako znak niespełnionej, nieszczęśliwej miłości;

2) nowy - romantyczny sposób poznania rzeczywistości;

3) tęsknota za utraconym szczęściem, połączona z gorzką melancholią; wyraz samotności, opuszczenia, utraty jakiegoś dobra;

4) doświadczenie bliskości Boga, możliwość odsłonięcia przed Nim rozterek własnej duszy.

Powyższe kwestie są przedmiotem rozważań w przygotowanej przeze mnie rozprawie doktorskiej zatytułowanej Motyw łez w liryce polskich poetów romantycznych ${ }^{1}$. Wskazanie zaledwie kilku problemów związanych z tytułowym

\footnotetext{
1 Dysertacja została przygotowana pod kierunkiem Grażyny Halkiewicz-Sojak.
} 
motywem w lirykach religijnych Słowackiego, pozwoli dostrzec ważność tego wątku w poszukiwaniu odpowiedzi na pytanie o intensywność przeżyć, ich „szczerość" weryfikowaną także poprzez przywołanie tła biograficznego. Niniejsze rozważania są kolejnym etapem moich analiz ukazujących sposób sfunkcjonalizowaniu tematu łez w liryce Słowackiego ${ }^{2}$.

$\mathrm{O}$ obecności $w$ jego wierszach form modlitewnych pisała między innymi Joanna Kułakowska ${ }^{3}$. Motywy i pierwiastki sakralne, jak również elementy modlitewne $\mathrm{w}$ liryce romantycznej były przedmiotem badań także innych autorów: Stefanii Skwarczyńskiej, Stefana Sawickiego, Ireny Sławińskiej, Czesława Zgorzelskiego ${ }^{4}$. Z uwagi na kierunek moich rozważań, który jest zbliżony do stanowisk wymienionych badaczy, to właśnie ich ustalenia będą przywołane w dalszej części artykułu. Na wstępie warto wskazać kilka miejsc wspólnych dla obydwu utworów, takich jak: pełna "nabożnej czci” postawa „ja" lirycznego wobec Boga, apostroficzny (zwrot do Chrystusa), modlitewny charakter wypowiedzi, kontemplacja motywów pasyjnych, poszukiwanie Tajemnicy. Inaczej ukształtowana przestrzeń liryczna wierszy odpowiednio różnicuje nastrój wypowiedzi, jak również odmiennie wpływa na ich sugestywność. Nasuwające się zatem pytania związane z motywem łez dotyczą zarówno sposobu kreacji „podmiotu wierzącego”, jak również źródła płaczu, rodzaju emocji.

Doświadczenie przez Słowackiego Bożej obecności przypada na czas jego pobytu w Ziemi Świętej. Towarzysząca religijnemu zadumaniu rozpacz poety u grobu Chrystusa została wyrażona w wierszu I porzuciwszy droge światowych omamień... Sugestywność liryku wzmacnia świadomość autentycznych wydarzeń, jakie miały miejsce podczas podróży poety na Wschód. Atmosferę chwil spędzonych u Grobu Zbawiciela oddają fragmenty listu poety:

Z dnia 14 na 15 miałem przepędzić noc u Grobu Chrystusa... Na wspomnienie tej nocy (tak miałem rozigrane nerwy), że łzy rzucały mi się z oczu. - Noc u grobu Chrystusa przepędzona zostawiła mi mocne wrażenie na

2 Zob. A. Mazur, Rozmowa wieczorna Adama Mickiewicza - modlitwa zrozpaczonego poety, w: Kultura i rozpacz. Analizy ekspresji rozpaczy w tekstach kultury, red. D. Brzeziński, A. Kapusta, Kraków 2009; Łzy pamięci poety. Rozważania nad płaczliwa motywika w późnych wierszach Juliusza Słowackiego, w: Piękno Juliusza Stowackiego, t. 2, red. J. Ławski, K. Korotkich, G. Kowalski, Białystok 2013, s. 507-519.

3 Zob. J. Kułakowska, Formy modlitewne w twórczości Słowackiego. Od "Hymnu" do "Zachwycenia", Kraków 1996.

4 Zob. S. Skwarczyńska, Studia i szkice literackie, Warszawa 1953; S. Sawicki, Z pogranicza literatury i religii, Lublin 1979; S. Sawicki, Religia a literatura, w: Inspiracje religijne w literaturze, red. A. Merdas, Warszawa 1983; S. Sawicki, Sacrum w literaturze, w: Sacrum w literaturze, red. J. Gotfryd, Lublin 1983; I. Sławińska, Inspiracje religijne w literaturze polskiej, "Znak” 1984, nr 4. 
zawsze. O godzinie 7 wieczór zamknięto kościół - zostałem sam i rzuciłem się z wielkim płaczem na kamień grobu. Nade mną płonęło 43 lamp. Miałem bibliją, którą czytałem do 11-stej w nocy. O pół do dwunastej weszła do grobu młoda kobieta i mężczyzna, jak sądziłem małżonkowie, którzy musieli mieszkać w klasztorze i zrobili votum odmawiać co dnia pacierz w nocy na grobie. Jakoż oboje pomodlili się krótko, pocałowali w kamień, a potem, przyszedłszy do mnie, oboje pocałowali mnie w rękę. Tak byłem zamieszany, że nie wiedziałem jak się znaleźć [...] o drugiej zaś w nocy ksiądz rodak (Maksymilian Ryłło) ${ }^{5}$ wyszedł ze mszą na intencją mojej kuzynki, a ja klęcząc na tym miejscu, gdzie anioł biały powiedział Magdalenie: „Nie ma go tu, zmartwychwstał!”, słuchałem całej mszy z głębokim uczuciem. O trzeciej w nocy, znużony, poszedłem do klasztoru i spałem snem dziecka, które się zmęczy łzami.

\section{Ponownie wspomina o tym autor Kordiana z Livorno:}

Przepędziłem całą jedną noc sam jeden w Grobie Chrystusa, modląc się za ciebie i za naszych. [...] Byłem w Betlehem, w Yerycho, w Nazaret... nad Jeziorem Genzaretańskim, gdzie Chrystus mi był przed oczyma. Zdawało mi się, że postać jego spokojna stoi jeszcze na błękicie fali, z głową otoczoną promieniami ${ }^{6}$.

Wiersz I porzuciwszy... jest liryczną syntezą przeżyć, o których mowa w listach:

I porzuciwszy drogę światowych omamień, I wysłuchawszy serca - gdy rzekło: Jam czyste!

Tu rzuciłem się z wielką rozpaczą na kamień, Pod którym trzy dni martwy leżałeś, o Chryste! Skarżyłem się grobowi - a ta skarga była Ani przeciwko ludziom - ani przeciw Bogu... ${ }^{7}$

Bez trudu można wskazać miejsca wspólne przywołanych wypowiedzi, co wiąże się $\mathrm{z}$ doznaniami poety $\mathrm{w}$ sytuacji religijnego poruszenia. Na uwagę

5 Informacje na ten temat zostały odnotowane w Kalendarzu życia i twórczości Stowackiego. Dokładnie opisuje tę sytuację ks. P. Semenenko w liście z 5 marca 1838 r. do ks. Franciszka Koryckiego: „W o. Rylle będziesz miał towarzysza, jakiego tylko życzyć sobie możesz. W Jeruzalem, przy żłobie Pańskim, kiedy mszę mówił, Słowacki Juliusz służył mu do mszy. «Przykryłem - powiada - szpetność orła moskiewskiego». Trzeba bowiem wiedzieć, że Moskale wystawili orła swego przy żłobie Pańskim, tego tedy przykrył o. Ryłło jako godło zdrady, rozboju, odszczepieństwa i bezbożności...". Kalendarz życia i twórczości Juliusza Słowackiego, oprac. E. Sawrymowicz, przy współpr. S. Makowskiego i Z. Sudolskiego, Wrocław 1960, s. 282.

6 Korespondencja Juliusza Słowackiego, oprac. E. Sawrymowicz, t. 1, Wrocław 1962, s. 349, 362.

7 J. Słowacki, Wiersze. Nowe wydanie krytyczne, oprac. J. Brzozowski, Z. Przychodniak, Poznań 2005, s. 186. Wszystkie cytaty utworów Juliusza Słowackiego pochodzą z tego wydania. W tekście głównym podaję stronę, na której jest zamieszczony utwór. 
zasługuje sposób mówienia o doświadczaniu Tajemnicy, jak również rodzaj uobecnienia Sacrum. Narracyjny, opisowy charakter listu umożliwia wejrzenie w szczegóły podróży związane z miejscem, wyglądem przestrzeni, w jakiej przebywał pielgrzym. Szczególnie interesująca jest emotywność listu. Wyrażone $\mathrm{w}$ wierszu przeżycia poety osiągają apogeum $\mathrm{w}$ zakończeniu, w którym, paradoksalnie, sugestywność wypowiedzi ulega ściszeniu, pozornemu wygaszeniu. Już pierwsze słowa relacji określają stan uczuć twórcy „rozigrane nerwy”, zaś poetyckim dopełnieniem tego niepokoju są łzy „rzucające się z oczu”. Kolejne określenia ukazują wnętrze osobowego ,ja”, jak również pozwalają rozpoznać stopień intensywności doznań: „mocne wrażenie", „wielki płacz”, ,głębokie uczucie”, w końcu - „łzy”, wchodzące wprawdzie w skład porównania i dotyczące sytuacji utulonego płaczem dziecka, jednak w kontekście wcześniejszych informacji peryfrastycznie domykające obraz emocjonalnego rozedrgania pod wpływem religijnego przeżycia. Uzasadnieniem powyższej refleksji nad fragmentem listu Słowackiego jest dążenie do zasygnalizowanego na wstępie rozważań rozpoznania intensywności, jakości doznań podmiotu mówiącego uzewnętrznionych w wierszu. Szerszy ogląd spraw związanych zarówno z momentem poprzedzającym dotarcie Słowackiego do Ziemi Świętej, jak i z samym pobytem pozwala zauważyć, iż był to okres przygotowania do duchowej odmiany. Zachowane w pamięci szczegółowe informacje na temat zdarzeń, jakie składały się na dobowy rytm przebywania poety $\mathrm{w}$ świętym miejscu uwieńczonego głębokim zamyśleniem nad istotą wiary, odpowiednio dopełnia sensy obecne w liryku.

Introdukcją miniatury lirycznej I porzuciwszy... są słowa paralelne pod względem składniowym:

I porzuciwszy drogę światowych omamien,

I wysłuchawszy serca - gdy rzekło: Jam czyste.

Dwa anaforyczne wersy jednocześnie ukazują różne sytuacje egzystencjalne. $\mathrm{W}$ pierwszym $\mathrm{z}$ nich poeta odsłania własną postawę wobec minionych zdarzeń. „Omamieniami” nazywa czas złudnych nadziei - być może podążanie za młodzieńczymi uniesieniami serca bez szansy na powodzenie, pragnienie życzliwego przyjęcia własnej twórczości przez czytelników, salonowe obyczaje prowadzące do sztucznych postaw i zachowań utrudniających "prawdziwą" komunikację między ludźmi. Owe sensy uzupełniają słownikowe znaczenia słowa „omamienia”. Jego użycia w ówczesnym języku zostają odnotowane w Stowniku Samuela Lindego: „omamienie - «stan tego, kogo omamiono; to, co łudzi, omamia, omam, złuda, złudzenie, iluzja; oczarowanie, zaczarowanie». Omamiać - «wprowadzić w błąd, zwieść, otumanić, 


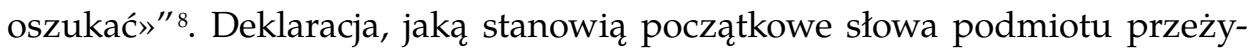
cia, o porzuceniu czy raczej odrzuceniu dawnych marzeń to jaskrawy przejaw funkcjonalizacji obecnej już we wczesnej liryce Słowackiego kategorii „braku”. Ów brak - tożsamy dla Kleinera z nieobecnością zaplecza biograficznego w lirycznym uzewnętrznianiu własnych pragnień, wyraźnej niechęci ,ja" lirycznego do tego, co minione - nabiera szczególnego znaczenia poprzez przeniesienie ciężaru semantycznego związanego z "przeszłymi czynami" na aktualną sytuację podmiotu. W celu dostrzeżenia poetyckiej funkcjonalności „braku” należy wskazać obecność tej kategorii we wczesnych utworach Słowackiego. Kleiner pisał o sonetowej formie ukazywania emocji jako nie dość sugestywnej ekspozycji wnętrza twórcy spowodowanej brakiem wystarczających inspiracji w życiu autora. Tymczasem jego doznania w okresie przebywania w Ziemi Świętej mają już zupełnie odmienny charakter, inny jest rodzaj motywacji przeżyć widocznych zarówno w emocjonalnym tonie listów, jak również podobnej skali uczuć wyrażonych w tekstach poetyckich ${ }^{9}$. Pragnienie doświadczenia Bożej bliskości ma konkretne źródło zaświadczone fragmentami korespondencji - choroba matki, śmierć babki ${ }^{10}$. Należy do nich również wiele doświadczeń poprzedzających podróż poety na Wschód (klęska zrywu powstańczego, świadomość daremności działań zmierzających do odzyskania niepodległości, w konsekwencji zaś - konieczność rozstania z najbliższymi). Obraz wewnętrznych zmagań twórcy podczas wędrówki na Wschód, jak również wskazówki na temat czynnika motywującego jego przeżycia wyrażone w I porzuciwszy... przynoszą fragmenty poematu Podróż do Ziemi Świętej. Interesujące są spostrzeżenia na ten temat Marii Kalinowskiej, która podkreśla ważność kilku tematów (motyw morza, temat śmierci) dla zrozumienia sensów zawartych $w$ utworze, jak również zwraca uwagę na współwystępowanie tonacji serio oraz ironii ewokujących stan emocjonalny poety:

W taki sposób poeta wyruszający $\mathrm{w}$ wielką podróż na Wschód, znanym szlakiem romantycznym - przez Grecję do Ziemi Świętej - postrzega siebie i swoje życie: jako zagubienie w nicości, jako doświadczenie marności zarówno świata, jak i dotychczasowej swojej egzystencji. [...] W końcowych strofach pieśni I w sposób już całkowicie jednoznaczny i pozbawiony ironicznego dystansu

\footnotetext{
8 S. B. Linde, Słownik języka polskiego, t. 3, Lwów 1857, s. 549.

9 Na szczególną uwagę w tym kontekście zasługuje poemat - Podróż do Ziemi Świętej z Neapolu wraz z Dziennikiem - rodzajem diariusza odsłaniającego różnorodne spostrzeżenia, obserwacje poety dotyczące poznawanej przestrzeni, jak również pozwalającego rozpoznać stan duchowy Słowackiego.

10 Zob. Korespondencja Juliusza Stowackiego, oprac. E. Sawrymowicz, t. 1, Wrocław 1962, s. 220.
} 
przedstawia poeta swoje zagubienie na „drogach bezludnych" „świata szalonego", bardzo podobne "obłąkaniu na wielkim morzu". [...] Jest to więc człowiek nie pogodzony ze swoim życiem; ktoś, kto nie potrafi ustabilizować się wewnętrznie i nie może osiągnąć dojrzałości, pełni istnienia $[\ldots]^{11}$.

Słowa o porzuceniu wypowiada zatem $\mathrm{w}$ wierszu osoba $\mathrm{w}$ pełni świadoma własnych celów. W konsekwencji umożliwia to pełniejsze funkcjonowanie "Ja" zarówno w świecie zewnętrznym, jak i wewnętrznym ${ }^{12}$. W kontekście analizowanego wiersza nacisk należy położyć na samoświadomość autora, co wiąże się z przestrzenią sakralną, która sprzyjała refleksji nad istotą wiary oraz własnej postawy wobec Boga. To powoduje, że „brak” wpisany w dawną twórczość Słowackiego zostaje spotęgowany. Poetycki zaś temat wcześniejszych wierszy dotyczący kwestii miłosnego zawodu zostaje podważony w planie ideowym. Konsekwencje tej deklaracji mają szersze znaczenie. W porzuceniu dawnego życia można dostrzec swego rodzaju wychylenie poety ku przyszłości stanowiącej dalszy etap duchowego rozwoju podmiotu, co wiąże się $\mathrm{z}$ pragnieniem pełnego doświadczenia Boga.

Czynnikiem istotnym dla odczucia Bożej bliskości jest pokorna wobec Stwórcy postawa poety. W modlitwie Słowackiego owa postawa pozbawiona jest tych pierwiastków, jakie można dostrzec $\mathrm{w}$ nieco wcześniejszym hymnie - Smutno mi, Boże. Wyraźna sugestia na temat adresata wypowiedzi zawarta $\mathrm{w}$ tytule liryku nie ma rozwinięcia $\mathrm{w}$ dalszych fragmentach utworu. Wiersz ten wypełnia bowiem $\mathrm{w}$ stopniu nadrzędnym treść przeżycia wypowiadającej się osoby, zaś „koncepcja Boga pełni funkcję uwznioślającego rezonansu"13. To pozwoliło Kułakowskiej wpisać wiersz do kręgu modlitw egocentrycznych ${ }^{14}$. Zgorzelski natomiast traktował hymn jako przykład innego kierunku twórczości autora Kordiana, nieprzystającego do jego nowej drogi życia, którą zapoczątkowała wędrówka do Ziemi Świętej:

11 M. Kalinowska, Grecja romantyków: studia nad obrazem Grecji w literaturze romantycznej, Torun 1995, s. 56-57. Zob. M. Kalinowska, Juliusza Słowackiego "Podróż do Ziemi Świętej z Neapolu”. Glosy, Gdańsk 2011.

12 Przywołane w tym fragmencie liczne określenia, pojemne semantycznie leksemy są zaczerpnięte z książki Agnieszki Ziołowicz Poszukiwanie wspólnoty. Estetyka dramatyczności a więz międzyludzka w literaturze polskiego romantyzmu (preliminaria), Kraków 2011. Rozpoznanie sposobu funkcjonowania tytułowej kategorii w literaturze romantyzmu badaczka poprzedziła rozważaniami nad współwystępowaniem kategorii „Ja” z kategorią „My” - wspólnotowym obszarem aktywności człowieka. Jej refleksje, do których kontekstowo będę nawiązywać w dalszej części pracy, mają znaczenie w kontekście rozpoznania podmiotowości poetyckiej wypowiedzi, procesu odkrywania autentyczności przeżyć. Zob. A. Ziołowicz, Poszukiwanie wspólnoty, s. 5-15.

13 J. Kułakowska, Formy modlitewne w twórczości Stowackiego. Od "Hymnu" do "Zachwycenia", Kraków 1996, s. 47.

14 Zob. tamże, s. 39-54. 
Ani pobudka bojowa w powstańczym Hymnie do „Bogarodzicy”, ani elegijna skarga rozżalonego emigranta w Hymnie [„,Smutno mi, Boże!...”] nie prowadzą bynajmniej ku perspektywom, jakie otworzą się przed Słowackim już niebawem. [...] dopiero pogłębienie owych modlitewnych, egzaltacyjno-sentymentalnych uniesień z okresu szwajcarskiego, dokonywane już po zetknięciu z Towiańskim, poprowadzą go wprost ku nowej drodze życia i twórczości.

I wtedy dopiero w jego osobistym notatniku pojawią się jakby w bezpośrednim, naturalnym odbiciu tych silniejszych drgnień duszy pierwsze zapowiedzi zwrotu ku pogłębionej liryce religijnej okresu mistycznego. Pierwszą z nich jest [...] przypomnienie nocy spędzonej u grobu Chrystusa, a jednocześnie akt skruchy i wielkiej rozpaczy w skardze ani „,ani przeciwko ludziom - ani przeciw $\mathrm{Bogu}^{\prime 15}$.

W świetle uwag badacza wiersz I porzuciwszy... to świadectwo duchowej przemiany podmiotu przeżycia, ale też ważne źródło dla zrozumienia uczuciowości Słowackiego opisywanej przeze mnie za pomocą motywu łez. W celu dopełnienia kwestii związanych z liryczną wartością płaczu ${ }^{16}$, konieczne jest przyjrzenie się poszczególnym fragmentom refleksji poetyckiej. To zaś skłania do ponownego - kontekstowego przywołania hymnu - Smutno mi, Boże. Jego obecność pozwoli wskazać różnice w sposobie prowadzenia wątku lirycznego w wierszu I porzuciwszy... oraz dostrzec cechy modlitewności utworu. Ukazanie tych odmienności w zakresie formalnym i semantycznym jest możliwe dzięki położeniu nacisku na relację: podmiot przeżycia - Bóg.

Drugi człon wiersza tworzący wspólnie z pierwszym wersem konstrukcję poetycką opartą na paralelizmie składniowym, stanowi wyraźny zwrot ku przedmiotowi przeżycia - Chrystusowi. Lapidarne dwa pierwsze wersy są zapisem duchowego odrodzenia poety, zmiany horyzontu postrzegania świata i własnego istnienia. „Porzucenie drogi światowych omamień" to rodzaj podniesienia po raz kolejny - być może ostatni? - własnej podmiotowości, przywołanie minionych zdarzeń ilustrujących sposób postrzegania rzeczywistości przez pryzmat swojej wyjątkowej osobowości. Słów dotyczących „porzucenia” nie należy jednak traktować w kategoriach świadectwa zupełnej rezygnacji poety z indywidualności. Moc sprawcza „odrzucania” przeszłych czynów przynależy przecież właśnie twórcy. Postawa skruchy, uznania własnej wobec Boga małości zostaje uwidoczniona w kolejnych wersach

15 C. Zgorzelski, „W Tobie jest światłość”. O liryce religijnej Słowackiego, w: Polska liryka religijna, red. S. Sawicki, P. Nowaczyński, Lublin 1983, s. 90, 91.

16 O lirycznej wartości motywu płaczu w kilku wybranych wierszach Słowackiego pisała między innymi Kuczera-Chachulska. Zob. rozdz. „Płacz” Słowackiego. Liryczna wartość motywu, w: taż, Przemiany form i postaw elegijnych w liryce polskiej XIX wieku, Warszawa 2002, s. 159-174. 
rozpoczynających się od krótkiego westchnienia: „I wysłuchawszy serca ${ }^{17}$, gdy rzekło: «Jam czyste»", po którym następuje otwarcie "serca czystego" przed Bożym - Chrystusowym obliczem: „Tu rzuciłem się z wielką rozpaczą na kamień, / Pod którym trzy dni martwy leżałeś, o Chryste!". Serce - „ideał chrześcijańskiej pokory” i jednocześnie dla romantyków - jedno z ważniejszych źródeł poznania opartego między innymi na czuciu, intuicji ${ }^{18}$ - stanowi zarówno czynnik konieczny do zaistnienia pełniejszego doznania numinotycznego, jak również uzewnętrznienia własnych wobec Pana rozterek, cierpień wyrażonych $\mathrm{w}$ wierszu w jednym, sugestywnym słowie „rozpacz”, spotęgowanym epitetem „wielka”. Mimo dużej skali wewnętrznego poruszenia, centralne miejsce tej "modlitewnej skargi" 19 skierowanej w formie emotywnej apostrofy do Boga - „martwy leżałeś, o Chryste!” zajmują nie tylko przeżycia podmiotu, ale też zostaje $\mathrm{w}$ niej ukazana postawa poety wobec Najwyższego. Zdaniem Kułakowskiej ta cecha pozwala określić wiersz mianem modlitwy teocentrycznej zorientowanej emocjonalnie. Bóg stanowi w tym wierszu odbiorcę trudnego do wysłowienia smutku twórcy. "Wielka rozpacz", podobnie jak ciche, sekretne „wylewanie duszy we łzy roztopionej" w Rozmowie wieczornej Mickiewicza to rodzaj pozawerbalnego kontaktu z Bogiem. Podobnie jak w utworze Mickiewicza przestrzeń liryczna jest w wierszu niedookreślona. Nie wiadomo, czy sytuacji zamyślenia pielgrzyma nad grobem Chrystusa towarzyszą inne osoby, czy też odbywa się ona w zupełnej samotności. Kilka konkretnych informacji na ten temat można wprawdzie odnaleźć w listach Słowackiego, jednak brak takich przesłanek w utworze wpływa na sugestywność lirycznej refleksji - potęguje oddziaływanie smutku pielgrzyma. Wydaje się zatem, że w obydwu przypadkach „rozmową" można nazwać myśl zwróconą do Stwórcy w geście pokornego ukłonu oraz z prośbą o wysłuchanie. Obydwaj poeci otrzymują bowiem od Niego „odpowiedź" we własnym sercu. W wierszu Słowackiego

17 Motyw serca obecny w wierszu koresponduje ze sposobem pojmowania „serca" przez Krasińskiego. Ziołowicz - rekonstruując funkcjonalizację tego motywu w twórczości autora Irydiona, wpisała go w krąg problematyki związanej z kategorią wspólnoty i wskazała na jego chrześcijański rodowód: „Stawiając hrabiego Henryka przed dylematem: żyć w sobie, czy żyć dla innych, opowiadał się jednoznacznie za drugim rozwiązaniem, w korespondencji motywując ten wybór antropologiczną rangą serca, ideałem chrześcijańskiej pokory i wielkoduszności, koncepcją "zapoznanej ofiary, świętszej niż sława»". Zob. A. Ziołowicz, Poszukiwanie wspólnoty. Estetyka dramatyczności a więź międzyludzka w literaturze polskiego romantyzmu (preliminaria), Kraków 2011, s. 3.

18 Zob. M. Cieśla-Korytowska, O romantycznym poznaniu, Kraków 1997.

19 J. Kułakowska, Formy modlitewne w twórczości Słowackiego. Od "Hymnu" do "Zachwycenia", Kraków 1996, s. 60. 
„wielka rozpacz", jaka towarzyszy doznaniu Tajemnicy połączona z równie gwałtownym gestem „rzucenia się" na grób Chrystusa, zostaje odpowiednio stłumiona poprzez skargę - o nieujawnionej motywacji - złożoną przez poetę grobowi. Towarzyszy jej równie nieokreślony żal podmiotu: „Skarżyłem się grobowi, a ta skarga była / Ani przeciw ludziom - ani przeciw Bogu...". W przestrzeni rzeczywistej wiersz ukazuje dotarcie pielgrzyma do celu swej podróży - miejsca, które uobecnia źródło chrześcijaństwa. Metaforycznie zaś wędrówkę, pielgrzymkę, podróż można odczytać jako obraz życia poety. W tym znaczeniu jego rozpacz byłaby rodzajem podsumowania dotychczasowych doświadczeń i jednocześnie - na skutek obecności ,ja” przeżywającego w przestrzeni sakralnej - symbolem oczyszczenia, początku nowej drogi życia. Lakoniczność utworu pozwala jednak przyjąć tylko hipotetycznie rozwiązania interpretacyjne. Niemożność jednoznacznego wskazania źródła bólu to najbardziej sugestywne świadectwo pokory, bo jedyną motywacją rozpaczy jest kontemplacja Chrystusowego cierpienia. Brak wyraźnego zakończenia (paralelny do braku wstępu) sprawia wrażenie nagłego przerwania wypowiedzi w poczuciu niewystarczalności języka dla wyrażenia całego bogactwa doznań - przenosi tę refleksję, ograniczoną do słów najbardziej potrzebnych, w bezgłośną kontemplację. Można też mniemać na podstawie wcześniejszych eksplikacji, że zastygnięciu w słowie będzie odpowiadał gest dłuższego znieruchomienia na grobie Zbawiciela wzmacniający autentyczność wypowiedzi.

Omówiony powyżej utwór wspólnie z fragmentem - [Czyż dla ziemskiego tutaj wojownika...] stanowiącym parafrazę siódmego rozdziału Księgi Hioba („,Czyż nie do bojowania podobny byt człowieka? / Czy nie pędzi on dni jak najemnik? / Jak niewolnik, co wzdycha do cienia, / jak robotnik, co czeka zapłaty. / Zyskałem miesiące męczarni, / przeznaczono mi noce udręki" - Hi 7, 1-3) został określony przez Zgorzelskiego jako zapowiedź nowych wyzwań zarówno twórczych, jak i życiowych ${ }^{20}$. Wypada tutaj wspomnieć o przełomie duchowym twórcy pod wpływem towianizmu, który został zainicjowany przyjęciem „idei nowej wiary”, co odzwierciedla znacznie późniejszy wiersz Tak mi Boże dopomóż. Przemiana wewnętrzna poety została też uzewnętrzniona za pomocą onirycznego obrazowania w innym utworze Śni mi się jakaś wielka a przez wieki idąca..., gdzie łzy są oznaką uczuć niechcianych przez autora, ponieważ są wyrazem niemocy działania i bezradności człowieka:

20 Zob. C. Zgorzelski, Liryka w petni romantyczna. Studia i szkice o wierszach Słowackiego, Warszawa 1981, s. 216, 217. 
Śni mi się jakaś wielka a przez wieki idąca

Powieść... niby na twarzy ogromnego miesiąca [...] - O pomóż, Zbawicielu,

Abym te wszystkie rzeczy... do gwiazdy i do celu

Doprowadził... a ludzkim się nie zmieszał oklaskiem

Ani łzami się zalał... ani śćmił Twoim blaskiem.

[s. 394]

Wyraźne sygnały nowych podniet, jakie miały odtąd decydować o artystycznych i życiowych wyborach Słowackiego, można także odnaleźć w liście poety do Krasińskiego:

Mówię ci więc, drogi! że wkrótce szata z jęków, a hełm z błyskawic wyda się aktorstwem i sprzecznością śród prostoty i wypogodzonych twarzy [...] ileż razy ja sam jeszcze jęknę z największą rozpaczą, myśląc, że mnie wszystkie mary tego świata odbiegły - i nie został mi, jak Chrystus. [...] Praca więc powinna się zacząć w nas samych - to jest powinniśmy w sobie wyrabiać doskonałą moc czucia - zlewać go, spioruniać w sercu - a to wszystko z cichością i prostotą ludzi mocnych - i mających wielkie rzeczy do wypełnienia $[\ldots]^{21}$.

„Liryką lat ostatnich" został nazwany ten finalny etap twórczości poety. Należą do niego takie wiersze jak: Proroctwo, Do Ludwika Norwida, Powstał naród wykonawca..., Gdy noc głęboka wszystko uśpi i oniemi, Mój król [i] mój Pan to nie mocarz żadny..., O! wielki Boże - o Panie wszechmocny..., Aniot ognisty - mój anioł lewy..., Panie! jeżeli zamkniesz stuch narodu..., O krzyż cię prosze modlitwa gwałtowna, [Kiedy pierwsze kury Panu śpiewaja...]. Są to utwory realizujące różnorodne formy artystyczne: od wypowiedzi programowo-konfesyjnych, wierszy-proroctw, przez piosenki, wiersze medytacyjno-kontemplacyjne, aż po miniatury liryczne. Danuta Zamącińska nazwała wypowiadającą się w tych utworach osobowość „niezwykłą" i „elitarną", w końcu „samowystarczalną" 22, bo trudno oczekiwać od odbiorcy pełnej - popartej własnym doświadczeniem, jak również sobie właściwą wyobraźnią - percepcji tych wierszy.

Oderwanie od historii ma szczególne znaczenie w wierszu Panie, o którym na niebiosach styszą... Szczególny charakter wiersza przejawia się między innymi w sposobie ukazania relacji: podmiot przeżycia - Bóg. Mimo uzewnętrznienia własnych doznań wyrażonych płaczem, akcent pada na doświadczenie Bożej obecności jako źródła uczuć autora. W kontekście tych

21 Korespondencja Juliusza Stowackiego, oprac. E. Sawrymowicz, t. 1, Wrocław 1962, s. 505, 506.

22 D. Zamącińska, Słynne - nieznane. Wiersze późne Mickiewicza, Słowackiego, Norwida, Lublin 1985, s. 53. 
ustaleń wydaje się właściwe oraz obiecujące pod względem interpretacyjnym zestawienie wiersza Panie, o którym na niebiosach słysze... z omówionym powyżej - I porzuciwszy drogę światowych omamień... Za zasadnością odczytania tych liryków we wzajemnym oświetleniu przemawia także kilka innych czynników: motywiczne podobieństwo dostrzegalne w emocjonalności wyznania zawartej w słowie „rozpacz”, jak również w geście „rzucenia” się tym razem - nie na grób Chrystusa, ale "twarzą na kamienie” 23 . Widoczne jest ono także w formie - obydwa utwory nazywane są przez badaczy "modlitewną miniaturą" 24 lub „westchnieniem modlitewnym” 25.

Utwór - podobnie jak poprzedni - ma lapidarną, fragmentaryczną konstrukcję ${ }^{26}$, co sugeruje pisanie pod wpływem niespodziewanego, gwałtownego poruszenia:

Panie, o którym na niebiosach słyszę,

Gdzie słychać grzmot słońc - albo gwiazd dzwonienie,

Panie, w którym ja nieraz się uciszę,

Gdy padnę we łzach - twarzą na kamienie.

Skala emocjonalnego przeżycia, od początkowych wersów cechującego się dużą intensywnością, ulega spotęgowaniu dzięki odpowiedniej konstrukcji wiersza - jego lakonicznej formie, kondensującej treści i uczucia „ja” mówiącego. W wierszu zostają uzewnętrznione zmagania poety z własną, świadomie przeżywaną bezradnością zarówno w obliczu ziemskich trudów, jak

$23 \mathrm{~W}$ tym motywie dostrzegalne jest jednak wymowne podobieństwo z postawą poety wobec Boga wyrażoną w geście „rzucenia” się na grób Chrystusa. Jest ona obecna w wierszu wcześniej napisanym I porzuciwszy... Na uwagę zasługuje w tym kontekście kamień jako symbol praprzyczyny, Boga, Chrystusa, Kościoła, męczeństwa, śmierci, grobu (W. Kopaliński, Słownik symboli, Warszawa 2001, s. 136). Ten trop prowadziłby zatem do dostrzeżenia paraleli motywów, które w obydwu przypadkach pełniłyby podobną funkcję - pozwalałyby uzewnętrznić stan emocjonalny podmiotu mówiącego w chwili głębokich doznań religijnych. To zaś wpływa na sposób obecności motywu łez w twórczości Słowackiego z wyraźnym jednak ograniczeniem pola obserwacji do utworów podejmujących temat wiary. Motyw ten byłby zatem nośnikiem konkretnych sensów, ale także, a może przede wszystkim znakiem określonych doznań poety rodzących się w sytuacji głębokiego namysłu nad istotą chrześcijaństwa.

24 Zob. J. Kułakowska, Formy modlitewne w twórczości Stowackiego. Od „Hymnu" do „Zachwycenia", Kraków 1996, s. 69.

25 C. Zgorzelski, Liryka w pełni romantyczna. Studia i szkice o wierszach Stowackiego, Warszawa 1981, s. 198.

${ }^{26}$ Utwór kilkakrotnie był interpretowany przez badaczy. Zob. między innymi: A. Boleski, Juliusza Stowackiego liryka lat ostatnich (1842-1848), Łódź 1949, s. 39; C. Zgorzelski, Liryka w petni romantyczna. Studia i szkice o wierszach Słowackiego, Warszawa 1981, s. 197-198; J. Kułakowska, Formy modlitewne w twórczości Stowackiego. Od "Hymnu” do „Zachwycenia”, Kraków 1996, s. 69; D. T. Lebioda, Stowacki - kosmogonia, Bydgoszcz 2004, s. 447. 
również szerzej - w wymiarze wertykalnym - wynikającą z poczucia własnej niedoskonałości wobec Stwórcy, o której w hymnie Smutno mi, Boże pisał autor: „Nim się przed moją nicością ukorzę”. W innym liryku powstałym $\mathrm{w}$ bliskim sąsiedztwie czasowym ${ }^{27}$ fragmentu Panie, o którym na niebiosach słyszą... nicość człowieka wobec nieskończoności Stwórcy świata została ukazana w sposób równie sugestywny. Bóg został wprawdzie pozbawiony atrybutów władcy - mocarza, króla, ale jednocześnie nic nie stracił w oczach poety ze swej wielkości. Jej miarą jest duchowa moc obecna w świecie oraz ponad nim:

Mój Król [i] mój Pan - to nie mocarz żadny

$\mathrm{Ni}$ ten - na którym trzy koron się piętrzy,

Ale duch pierwszy globu - światowładny,

Chociażby w chłopku - duch świata - najświętszy [...]

Skądkolwiek jego duch na mnie uderzy,

Gdziekolwiek jego wołanie usłyszę... [...]

Gdziekolwiek ono dziecko światowładne

Poczuję - klęknę i na twarz upadnę.

Po raz kolejny swą bezgraniczną ufność w Boże miłosierdzie wyrazi autor w westchnieniu modlitewnym - O! Wielki Boże - o Panie wszechmocny...: „O! wielki Boże - o Panie wszechmocny, / W Tobie jest światłość, siła mego łona" (480). Ta sama postawa poety wobec Stwórcy jest obecna w liryku Panie, o którym na niebiosach styszę... Funkcjonalność dychotomicznych zestawień, jakie są podstawą konstrukcji, polega na zderzeniu dwu osobowości - poety oraz Pana przedstawionych za pomocą przypisanych im atrybutów. Przedwieczny utożsamiony z niebiosami zostaje ukazany za pomocą słów ewokujących lub bezpośrednio nazywających dźwięk: „słyszę”, „słychać”, "grzmot słońc", "gwiazd dzwonienie". Motyw muzyki sfer wpisany w synestezyjny obraz przestrzeni przynależnej Bogu - z dominacją jednak słuchu nad wzrokiem - dopełnia owo wyobrażenie Stwórcy jako władcy "globowych sfer", świadczących o Jego nieograniczoności przekraczającej możliwości percepcyjne istoty ludzkiej. Po drugiej stronie tej opozycji znajduje się pełen pokory człowiek, który rozpaczliwie pragnie odnaleźć wewnętrzną harmonię, wyciszenie. „Modlitewne westchnienie” staje się zatem czymś więcej niż tylko chwilą zadumy nad potęgą Pana i związaną z tym potrzebą oddania

27 Autorzy Kalendarza życia i twórczości Juliusza Słowackiego umieszczali utwór Mój Król [i] Pan - to nie mocarz żadny między 31 sierpnia 1843 a początkiem sierpnia 1847 roku. 
$\mathrm{Mu}$ "czci" ${ }^{28}$. Jest także skierowaną do Najwyższego prośbą o zdjęcie z serca „jaskółczego niepokoju”, być może również „wyprorokowanie celu duszy”. Po raz kolejny poeta otrzymuje od Niego odpowiedź we własnym sercu „uciszenie" możliwe jest bowiem w chwili ofiarowania Mu trosk, kornego uznania własnej wobec Boga małości.

Liryki podejmujące temat wiary odsłaniają nowy etap życia oraz twórczości Słowackiego i równocześnie pozawalają dostrzec $\mathrm{w}$ tej poezji nowe sfunkcjonalizowanie romantycznych łez. Sugestywność wypowiadanej w wierszach rozpaczy - doświadczanej pod wpływem doznań religijnych jest równie duża. Dzieje się tak zarówno ze względu na poetyckie ukształtowanie wypowiedzi, jej lapidarny charakter, jak również biograficzne zaplecze ewokowanych w lirykach treści. Konsekwentne prowadzenie wątku lirycznego przejawiające się w formie „westchnień modlitewnych" złożonych z elementów najbardziej wyrazistych emocjonalnie pozwoliło odpowiednio umotywować doznania podmiotu przeżywającego. Źródło uczuć, jakim jest dla poety namysł nad Chrystusowym cierpieniem, doświadczenie bezradności w obliczu wielkości Boga, spełnia istotną funkcję w kontekście łez pojmowanych w kategoriach psychologiczno-fizjologicznego fenomenu - płaczu. Według klasyfikacji zawartej w książce Helmutha Plessnera, łzy poetów byłyby rodzajem osobowego płaczu, który należy umieścić pomiędzy płaczem "genetycznie najwcześniejszym [...] odpowiadającym strukturze prymitywnej, dziecięcej samoświadomości" 29 a płaczem duchowo określonym. Wydaje się, że to właśnie ostatni z wymienionych typów obejmujący „płacz wzruszenia, nabożeństwa, poświęcenia, który zakłada dojrzałą świadomość siebie i świata" ${ }^{30}$, odpowiada łzom poety stającego w obliczu religijnego przeżycia. "Świadomość wartości, wielkości”, poruszenie człowieka „w tym, co najbardziej jego własne" ${ }^{31}$, definiują postawę twórcy wobec Boga, ale nie są jedyne. Modlitewny zwrot do Przedwiecznego utrzymany w tonie pochwały, uwielbienia jest jednocześnie podziękowaniem za troskliwą opiekę, możliwość odnajdywania w Nim ukojenia "rozigranych nerwów” w skardze rzucanej „ani przeciw ludziom, ani przeciw Bogu”. Taki rodzaj "rozmowy” z Bogiem teocentrycznie emocjonalnej ${ }^{32}$ - skłania do dostrzeżenia zmiany w ekspono-

28 C. Zgorzelski, Liryka w petni romantyczna. Studia i szkice o wierszach Słowackiego, Warszawa 1981, s. 198.

29 H. Plessner, Śmiech i płacz. Badania nad granicami ludzkiego zachowania, przeł. i oprac. A. Zwolińska, Z. Nerczuk, posł. A. Zwolińska, Kęty 2004, s. 126.

30 Tamże, s. 127.

31 Tamże, s. 127.

32 Zob. J. Kułakowska, Formy modlitewne w twórczości Słowackiego. Od "Hymnu” do "Zachwycenia", Kraków 1996, s. 20. 
waniu przez podmiot mówiący własnego wnętrza. Indywidualizm romantyczny zyskuje w okresie powstania liryków religijnych Słowackiego nowe znaczenie. Jednak trudno odnieść wrażenie, iż ten etap życia i twórczości pozostaje zupełnie wolny od ekspozycji uczuć poety. Tym razem jednak źródło płaczu znajduje się na zewnątrz wypowiadającej się osoby. Będąc wartością od niej niezależną, pozwala jej jednocześnie odkryć oraz odczuć własną wielkość. Stąd głębokie poruszenie duszy znajdujące wyraz w płaczu. Niemożność jednoznacznego określenia emocji wywołujących wzruszenie uzewnętrznione płaczem (od łez uwielbienia, wdzięczności, przez łzy radości, szczęścia, po łzy oczyszczenia, moralnego odrodzenia, spełnienia) potęguje zawarte $\mathrm{w}$ wierszach emocje. Łzy obecne $\mathrm{w}$ wybranych utworach są sygnałem tych sensów, jakie pojawią się w kolejnym okresie wewnętrznych przeobrażeń twórcy. W tym momencie płacz zdaje się być jeszcze odpowiedzią na duchową niemoc poety, ograniczoność pojmowania stanowiącą dramatyczną przeszkodę w procesie odkrywania Prawdy - przed sobą, ale i przed światem. To właśnie pozostanie zadaniem do wypełnienia w kolejnym - mistycznym okresie twórczości Słowackiego.

\section{Complaint Prayer "Neither Against People - Nor Against God". Reflecting on the Motif of Tears in Two Poems by Juliusz Słowacki}

\section{Summary}

The article reinterprets the two poems which Juliusz Słowacki wrote while travelling to the Holy Land. Unlike in previous interpretations, here the author uses the motif of tears to uncover the poems' emotional value and to situate them in the tradition of romanticism. Other poems from the same period set the interpretative context and anticipate the poet's spiritual growth. Consequently, the article is yet another attempt to demonstrate the emotive characteristics of Słowacki's lyric poetry. Moreover, it shows how his works are related to his biographical background.

Keywords: lyric poetry, Juliusz Słowacki, motif of tears, autobiographism 